\title{
Early nutrition and metabolic outcome
}

\author{
Veronica Merica \\ From 8th APPES Biennial Scientific Meeting \\ Darwin, Australia. 29 October - 1 November 2014
}

In recent years the number of extremely premature born (very low birth weight $(\mathrm{VLBW}<1500 \mathrm{~g})$ children has increased as a consequence of increased survival rate. Those preterm neonates who survive have an increased risk of long-term neurological disabilities and chronic pulmonary disease. In addition, in the last two decades alterations in body composition and increased metabolic risk have been added to the list of consequences. In order to evaluate whether early patterns of infancy anthropometry and nutrition have an impact in metabolic hormonal profile and body composition we have prospectively assessed two cohorts of preterm infants and results will be presented.

Published: 28 April 2015

doi:10.1186/1687-9856-2015-S1-014

Cite this article as: Mericq: Early nutrition and metabolic outcome.

International Journal of Pediatric Endocrinology 2015 2015(Suppl 1):014.

Submit your next manuscript to BioMed Central and take full advantage of:

- Convenient online submission

- Thorough peer review

- No space constraints or color figure charges

- Immediate publication on acceptance

- Inclusion in PubMed, CAS, Scopus and Google Scholar

- Research which is freely available for redistribution

Submit your manuscript at www.biomedcentral.com/submit 